Vol 14, Issue 10, 2021

\title{
PHYTOCHEMICAL SCREENING, TOXICITY EVALUATION OF POLYCARPAEA CORYMBOSA LAMK AND ITS EFFECT ON CANCER BIOMARKERS OF EHRLICH ASCITES CARCINOMA-INDUCED MICE COMPARED WITH THE REFERENCE STANDARD DRUG 5- FLUOROURACIL
}

\author{
SAKTHI ABIRAMI $\mathbf{M}^{1 *}$, MUTHUSAMY $\mathrm{P}^{2}$ \\ ${ }^{1}$ Department of Pharmacology, College of Pharmacy, Madras Medical College, Chennai, Tamil Nadu, India. ${ }^{2}$ Department of Pharmacognosy, \\ College of Pharmacy, Madras Medical College, Chennai, Tamil Nadu, India. Email: m36sakthiabirami@yahoo.co.in
}

Received: 25 May 2021, Revised and Accepted: 06 September 2021

ABSTRACT

Objective: The current investigation focuses on the study of efficacy of whole plant of Polycarpaea corymbosa Lamk in Ehrlich ascites carcinoma (EAC) inoculated Swiss albino mice.

Methods: The whole plant of P. corymbosa Lamk (WPC) was extracted with solvents of increasing polarity and their percentage yields were calculated. The major phytoconstituents present in the plant extracts were determined by standard chemical tests. Tumor was induced in mice by intraperitoneal injection of EAC cells $\left(1 \times 10^{6}\right.$ cells/mouse). The in vivo antitumor effect of extracts was assessed by monitoring the mean survival time, tumor volume, effect on hematological parameters, determination of lysosome specific cancer markers (cathepsin-D), $\beta$-D glucuronidase and acid phosphatase, liver marker enzymes (5'-nuclotidase and lactate dehydrogenase), membrane bound ATPase ( $\mathrm{Na}^{+} / \mathrm{K}^{+}$ATPase and $\mathrm{Mg}^{2+}$ ATPase), DNA, and RNA content.

Results: The percentage yield obtained were $9.87 \% \mathrm{w} / \mathrm{w}, 7.88 \% \mathrm{w} / \mathrm{w}$, and $16.56 \% \mathrm{w} / \mathrm{w}$ for petroleum ether, ethyl acetate, and ethanol extract, respectively. The phytochemical screenings of those extracts were performed. The order of activity of extracts was ethanol extract > ethyl acetate > petroleum ether. Among the extracts, Ethanol extract of $P$. corymbosa Lamk. showed a significant increase in life span and decrease in viable cancer cell number and tumor volume. The protective effect of the extract on the hemopoietic system at the dose $200 \mathrm{mgkg}$ was noted. The alterations in the hematological profile, lysosome-specific cancer markers, liver-specific cancer markers, and membrane-bound ATPases DNA and RNA were restored.

Conclusion: The ethanolic extract of $P$. corymbosa Lamk. possesses in vivo anticancer activity when compared to the tumor control group.

Keywords: Breast cancer, Polycarpaea corymbosa Lamk; Ehrlich ascites carcinoma, Phytochemistry, Flavonoids, Cancer markers, Membrane transport protein, Nuclei acids, Anticancer.

(C) 2021 The Authors. Published by Innovare Academic Sciences Pvt Ltd. This is an open access article under the CC BY license (http://creativecommons.org/ licenses/by/4.0/) DOI: http://dx.doi.org/10.22159/ajpcr.2021v14i10.42481. Journal homepage: https://innovareacademics.in/journals/index.php/ajpcr

\section{INTRODUCTION}

Cancer is the second most cause of the death worldwide which is characterized by abnormal growth of cells due to the insensitivity of genes. It affects people at all ages [1] where damage to the genetic material of the malignant cells in progeny was observed in common. The imbalance in pro-oxidant and antioxidant is an important cause of cancer. The oxidative stress build up in turn generates reactive oxygen species inside the cell which further progresses to cellular transformation, genomic instability, hyperproliferation, immortalization, angiogenesis, and metastasis [2]. Understanding the key enzymes involved in the disease progression is important to identify the new drug targets. The screening of new molecules or natural agents with potential antitumor activity was vital to spot the right drug for treating the disease with ease. Hence, the requirement of substitutes for the conservative chemotherapeutic drugs which is economical, easy accessible, and therapeutically active at nontoxic doses and combats chemoresistance to control the disease progress is required [1].

The plants which belong to the Caryophyllaceae family have potential source of secondary metabolites and have many medicinal properties [3]. The whole plant Polycarpaea corymbosa Lamk belongs to the family Caryophyllaceae (Synonyms-Achyranthus corymbosa). P. corymbosa Lamk was an annual or perennial herb consisted leaves which were opposite or appear in whorls, linear up to $3.5 \mathrm{~cm}$ long with a brittle at the tip. The flowering season of this plant was from August to September. Flowers were borne in compact heads at the end of stems. Sepals were silvery white, turning rich brown with age. Petals were small, pink to orange in color. Fruit was a minute ellipsoid capsule. It was distributed in India,
Burma, Ceylon, Western Peninsula and ascending the western Himalayas to 7000 feet [4]. It was used both internally and externally as remedy for venomous bites from reptiles and animals [5]. In traditional Chinese medicine, it was used to treat cough and in Indian traditional medicine; it was used in the treatment of jaundice and inflammatory swellings [6]. This plant has proven antioxidant [7-10], anti-inflammatory [11,12], antiulcer [13-15], antidiarrheal [16], antimicrobial [17], analgesic [18], hepatoprotective $[8,19,20]$, and androgenic [21] properties. The cytotoxic potential against colorectal adenocarcinoma, breast cancer, leukemia, and prostate carcinoma of human cell lines were evaluated, in which potential activity against breast cancer cell line [22] was observed. Hence, the current study was investigated to determine its efficacy in Ehlrich ascites carcinoma (EAC)-induced mice, an in vivo model.

\section{MATERIALS AND METHODS}

\section{Collection and identification of plant}

The whole plant of P. corymbosa Lamk (WPC) was collected in the month of August and September from Palayamkottai, Tirunelveli District, Tamil Nadu, India. The taxonomic identification of the material was authenticated by Dr. G.V.S. Murthy, Ph.D., Scientist F and Head, Botanical Survey of India, Southern Regional Centre, Coimbatore, India. The plant material was dried under shade, segregated, pulverized by a mechanical grinder, and passed through a 40 mesh sieve. The powdered plant material was stored in airtight containers and used for further research.

Preparation of extracts and preliminary phytochemical screening The air-dried powdered material of about $2 \mathrm{~kg}$ from the whole plant was successively extracted by hot continuous percolation method in 
Soxhlet apparatus by increasing the polarity of the solvents such as petroleum ether, ethyl acetate, and ethanol. Solvents used for this entire work were of analytical grade (Merck, Mumbai). The extracts were collected and filtered through Whatmann filter paper No. 40, and the solvents were recovered from the extracts under reduced pressure using rotary evaporator. The concentrated filtrate was then evaporated to dryness in vacuum at $35-40^{\circ} \mathrm{C}$. Then, the extracts were stored in screw capped vials at $4^{\circ} \mathrm{C}$ until further use. The percentage yield was calculated with reference to the crude material was calculated, and the preliminary phytochemical screening for alkaloids, carbohydrates, proteins and amino acids, glycosides, saponins, flavonoids, tannins and phenolic compounds, phytosterols, fixed oils, and fats was carried out $[23,24]$.

\section{Animals}

Swiss Albino mice (25-30 g) were maintained under standard laboratory conditions temperature $\left(27 \pm 2^{\circ} \mathrm{C}\right)$ with relative humidity of $55 \pm 5 \%$, in an experimental room under a $12 \mathrm{~h}$ light $/ 12 \mathrm{~h}$ dark cycle as per CPCSEA. Before the experiment, mice were kept under quarantine for a week for acclimatization to the laboratory conditions. They were fed with commercial pellet diet and normal drinking water was provided ad libitum. The approval of the Institutional Animal Ethical Committee was obtained whose reference number is $1 / 243 /$ CPCSEA dated 22 November 2013.

\section{Experimental protocol}

Acute toxicity study

As per guideline of Organization of Economic Co-operation and Development 423 , the acute toxicity studies of petroleum ether, ethyl acetate, and ethanol extract of WPC were carried out [25].

\section{Tumor cells}

EAC cells were obtained from the Amala cancer Research Centre, Kerala (Thrissur), India. The EAC cells were maintained in vivo in Swiss albino mice, by intraperitoneal (i.p) injection of $1 \times 10^{6}$ cells/mouse after every 10 days [12].

\section{Grouping of animals}

Male Swiss albino mice were divided into 6 groups $(\mathrm{n}=6)$ and Group I served as normal control; Group II served as disease control (Inoculated with $1 \times 10^{6} \mathrm{EAC}$ cells/mouse (i.p); Group III treated with pet ether extract (200 mg/kg b.w p.o) during induction; Group IV inoculated with $1 \times 10^{6}$ EAC cells/mouse and treated with ethyl acetate extract $(200 \mathrm{mg} / \mathrm{kg} \mathrm{b.w}$ p.o) and Group V inoculated with $1 \times 10^{6}$ EAC cells/mouse and treated with ethanol extract (200 mg/kg b.w p.o.); Group VI Inoculated with $1 \times 10^{6} \mathrm{EAC}$ cells/mouse and treated with standard drug 5 -fluorouracil ( $20 \mathrm{mg} / \mathrm{kg}$ b.w) for 14 days.

\section{Laboratory investigations}

Evaluation of body weight:

Body weight of the animals was recorded from the day 1 to day 15 of the study. Average body weight at $15^{\text {th }}$ day was determined. The mean survival time and percentage increase of life span were calculated using the following formula [26].

(Day of the first death +

Mean Survival Time (MST)in days $=\frac{\text { Day of the last death) }}{2}$

Percentage increase of life span (ILS) $=\{($ MST Test $/$ MST control $)-1\} \times 100$.

\section{Hematological profile evaluation}

After the last dose and 18-hr fasting, blood was collected from six mice under mild anesthesia for hematological evaluation in each group which includes red blood cells (RBC), hemoglobin ( $\mathrm{Hb}$ ), total white blood cells (WBC), and differential count (neutrophils, lymphocytes, and monocytes) [27].

\section{Tumor volume}

After the treatment period, animals were dissected, and the ascitic fluid was collected from the peritoneal cavity and its volume, packed cell volume were determined [12], and viability was assessed using trypan blue exclusion assay.

\section{Bio markers estimation}

One gram of liver tissue was taken and homogenized with $10 \mathrm{ml}$ of $0.1 \mathrm{M}$ cold tris buffer, $\mathrm{pH} 7.4$ and examined for lysosome specific cancer markers (Cathepsin-D) [28], $\beta$-D glucuronidase [29], and acid phosphatase [30], liver marker enzymes [31] (5'-nuclotidase) and lactate dehydrogenase [32], and membrane bound ATPase $\left(\mathrm{Na}^{+} / \mathrm{K}^{+}\right.$ ATPase [33] and $\mathrm{Mg}^{2+}$ ATPase [34], DNA [35], and RNA [36,37] content were estimated.

\section{Statistical analysis}

The results were expressed as mean \pm SEM or mean \pm SD.

\section{RESULTS}

The percentage yields of petroleum ether, ethyl acetate, and ethanol extract of WPC were $9.87 \% \mathrm{w} / \mathrm{w}, 7.88 \% \mathrm{w} / \mathrm{w}$, and $16.56 \% \mathrm{w} / \mathrm{w}$, respectively. The phytochemical screening of petroleum ether extract (PEEPC) revealed the presence of phytosterols, fixed oils, and fats. Ethyl acetate extract (EAEPC) possess alkaloids, carbohydrates, glycosides, fixed oils and fat, saponin, phenolic compounds and tannins, protein, and amino acids. The ethanol extract (EEPC) contains alkaloids, flavonoids, carbohydrates, glycoside, saponins, phenolic compounds, tannins, protein, and amino acids.

\section{Acute toxicity}

It was observed that treatment of animals with PEEPC, EAEPC, and EEPC did not show any changes in the autonomic or behavioral responses. Zero percent mortality was obtained for all the extracts of the WPC and hence the extracts were found to be non-toxic up to the dose of $2000 \mathrm{mg} / \mathrm{kg}$.

\section{Anticancer study}

From Table 1, it was observed that the animals treated with EAC have increase in body weight, decrease in mean survival time, percentage increase in life span, and increase in tumor volume, packed cell volume, and viable cell count than the extract treated groups. On comparing within the extracts, group V and VI showed potential activity. Similar results were not found in other treatment groups. In Group II, animals were died after 18 days of inoculation whereas the life span of group $V$ and VI was 6 weeks.

\section{Hematological parameters}

The haematological parameters namely RBC, $\mathrm{Hb}$, Total WBC count and differential count were observed for various extracts of the WPC as furnished in Table 2. In group II, RBC, Hb, Lymphocytes and monocytes were found to be decremented whereas total WBC count and neutrophils were observed to be incremented. Group V and Group VI has restored $\mathrm{RBC}, \mathrm{Hb}$, total WBC count and differential count.

Estimation of lysosomal marker enzymes, liver markers, $\mathrm{Na}^{+} / \mathrm{K}^{+}$- ATPase and $\mathrm{Mg}^{+}$-ATPase, DNA, and RNA

i. The Lysosomal Marker enzymes in liver of experimental groups were depicted in Table 3. In Group II, the activity of Cathepsin-D was elevated twice (41.19 \pm 1.75$)$, than the Group I $(21.73 \pm 0.19)$ ). $\beta$-D glucuronidase activity was increased $(38.78 \pm 1.25)$ by $56 \%$ in Group II when compared to Group I. The increase in the activity of acid phosphatase was 3-fold (9.14 \pm 0.24$)$ when compared to Group I. In Groups III - VI, the lysosomal marker enzyme levels were decreased compared to Group II.

ii. Table 4 depicts the activity of liver marker enzymes 5'-nucleotidase and LDH in experimental groups. The level of 5'-nucleotidase in Group II was elevated thrice (6.46 \pm 0.25$)$ when compared to Group I ( $2.58 \pm 0.10)$. Nucleotidase activity is increased when tumor occluding the bile ducts. 
Table 1: Body weight, Mean survival time, Percentage increase in life span, Tumour volume, PCV and Tumour cell count of various experimental animals treated WPC extracts

\begin{tabular}{|c|c|c|c|c|c|c|c|}
\hline \multirow[t]{2}{*}{ Groups } & \multirow[t]{2}{*}{ Bodyweight(g) } & \multirow{2}{*}{$\begin{array}{l}\text { Mean } \\
\text { survival } \\
\text { time (days) }\end{array}$} & \multirow[t]{2}{*}{$\%$ in life span } & \multirow[t]{2}{*}{$\begin{array}{l}\text { Tumour } \\
\text { volume (\%) }\end{array}$} & \multirow[t]{2}{*}{$\begin{array}{l}\text { Packed cell } \\
\text { volume (\%) }\end{array}$} & \multicolumn{2}{|c|}{$\begin{array}{l}\text { Tumour cell count } \\
\left(1 \times 10^{7} \text { cells } / \mathrm{ml}\right)\end{array}$} \\
\hline & & & & & & Viable & Non- viable \\
\hline Group II & $36.10 \pm 0.58$ & $17.08 \pm 0.68$ & - & $2.81 \pm 0.11$ & $1.3 \pm 0.10$ & $11.82 \pm 0.92$ & $0.34 \pm 0.02$ \\
\hline Group III & $33.20 \pm 0.27$ & $18.61 \pm 0.98$ & 28.06 & $2.67 \pm 0.08$ & $1.1 \pm 0.81$ & $10.32 \pm 0.87$ & $0.38 \pm 0.11$ \\
\hline Group IV & $29.91 \pm 0.07$ & $20.19 \pm 0.71$ & 37.48 & $2.10 \pm 0.09$ & $0.98 \pm 0.17$ & $9.11 \pm 0.25$ & $0.51 \pm 0.22$ \\
\hline Group V & $26.91 \pm 0.91$ & $29.18 \pm 0.91$ & 59.67 & $1.90 \pm 1.16$ & $0.53 \pm 0.07$ & $7.62 \pm 0.25$ & $0.68 \pm 0.03$ \\
\hline
\end{tabular}

Values were expressed as Mean \pm SD for 6 mice in each group

Table 2: Effect of WPC on haematological parameters

\begin{tabular}{llllll}
\hline Groups & RBC $\left(\mathbf{1 0}^{\mathbf{6}} / \mathbf{m m}^{\mathbf{3}}\right)$ & Hb $(\mathbf{g} / \mathbf{d l})$ & WBC $\left(\mathbf{1 0}^{\mathbf{3}} / \mathbf{c u} . \mathbf{m m}\right)$ & \multicolumn{2}{l}{ Differential count (\%) } \\
\cline { 3 - 5 } & & & & Neutrophils & Lymphocytes \\
\hline Group I & $4.54 \pm 0.28$ & $11.92 \pm 0.31$ & $9.75 \pm 0.53$ & $16.40 \pm 0.63$ & $81.48 \pm 3.12$ \\
Group II & $2.11 \pm 0.09$ & $6.92 \pm 0.11$ & $15.73 \pm 0.36$ & $61.17 \pm 2.17$ & $35.24 \pm 1.24$ \\
Group III & $3.45 \pm 0.11$ & $8.44 \pm 0.96$ & $13.31 \pm 0.35$ & $52.27 \pm 2.31$ & $40.92 \pm 2.44$ \\
Group IV & $4.08 \pm 0.22$ & $10.08 \pm 0.62$ & $11.78 \pm 0.42$ & $38.27 \pm 2.31$ & $53.42 \pm 2.79$ \\
Group V & $4.21 \pm 0.72$ & $11.22 \pm 0.52$ & $10.93 \pm 0.39$ & $17.04 \pm 0.62$ & $71.42 \pm 2.79$ \\
Group VI & $4.48 \pm 0.21$ & $11.59 \pm 0.17$ & $9.67 \pm 0.35$ & $16.60 \pm 1.97$ & $75.11 \pm 0.11$ \\
\hline
\end{tabular}

Values are expressed as Mean \pm S.D. $(n=6)$

Table 3: Effect of various extracts of WPC on the activities of lysosomal markers enzymes in liver of normal and experimental group of animals

\begin{tabular}{llll}
\hline Groups & $\begin{array}{l}\text { Cathepsin-D } \\
(\boldsymbol{\mu} \text { moles } \\
\text { of tyrosine } \\
\text { liberated/h/ } \\
\text { mg protein) }\end{array}$ & $\begin{array}{l}\boldsymbol{\beta} \text {-D-glucuronidase } \\
(\boldsymbol{\mu} \text { moles of } \\
\mathbf{p} \text {-nitrophenol } \\
\text { formed/min/mg } \\
\text { protein) }\end{array}$ & $\begin{array}{l}\text { Acid } \\
\text { phosphatase } \\
\text { ( } \boldsymbol{\mu \text { moles of }} \text { ( } \\
\text { liberated/min/ } \\
\text { mg protein) }\end{array}$ \\
\hline Group I & $21.73 \pm 0.19$ & $24.93 \pm 0.79$ & $3.79 \pm 0.11$ \\
Group II & $41.19 \pm 1.75$ & $38.78 \pm 1.25$ & $9.14 \pm 0.24$ \\
Group III & $33.27 \pm 1.53$ & $33.14 \pm 1.17$ & $8.75 \pm 0.80$ \\
Group IV & $29.30 \pm 1.10$ & $30.10 \pm 0.70$ & $6.27 \pm 0.20$ \\
Group V & $26.12 \pm 1.27$ & $25.90 \pm 0.59$ & $4.18 \pm 0.14$ \\
Group VI & $22.52 \pm 0.77$ & $24.32 \pm 0.82$ & $3.38 \pm 0.09$ \\
\hline
\end{tabular}

Values expressed as mean \pm S.D for 6 mice in each group

Table 4: Effect of various extracts of WPC on the activities of liver markers enzymes in normal and experimental group of animals

\begin{tabular}{lll}
\hline Groups & $\begin{array}{l}\text { 5'-nucleotidase } \\
\text { (units/mg protein) }\end{array}$ & $\begin{array}{l}\text { Lactate dehydrogenase } \\
\text { (units/mg protein) }\end{array}$ \\
\hline Group I & $2.58 \pm 0.10$ & $1.59 \pm 0.10$ \\
Group II & $6.46 \pm 0.25$ & $0.41 \pm 0.12$ \\
Group III & $5.88 \pm 0.17$ & $0.43 \pm 0.53$ \\
Group IV & $4.37 \pm 0.16$ & $0.48 \pm 0.09$ \\
Group V & $3.17 \pm 0.17$ & $1.18 \pm 0.08$ \\
Group VI & $3.38 \pm 0.16$ & $1.25 \pm 0.08$ \\
\hline
\end{tabular}

Values are expressed as mean \pm SEM for 6 mice in each group

In Group III-VI, the marker enzyme levels were decreased compared to the Group II. LDH activity in the liver of Group II $(0.41 \pm 0.12)$ was markedly declined in comparison to Group I $(1.59 \pm 0.10)$. In Group III-VI, the increase in LDH level of liver was observed compared to the Group II.

iii. Table 5 illustrated that the effect of different extracts of WPC on the activities of ATPases, nucleic acids in liver of normal and experimental
Table 5: Effect of various extracts of WPC on the activities of $\mathrm{Na}^{+} / \mathrm{K}^{+}$- ATPase and $\mathrm{Mg}^{+}$-ATPase in liver of normal and experimental group of animals

\begin{tabular}{lllll}
\hline Groups & $\begin{array}{l}\mathbf{N a}^{+} / \\
\mathbf{K}^{+} \text {-ATPase } \\
\text { (units/mg } \\
\text { protein) }\end{array}$ & $\begin{array}{l}\mathbf{M g}^{+} \text {-ATPase } \\
\text { (units/mg } \\
\text { protein) }\end{array}$ & $\begin{array}{l}\text { DNA } \\
\text { (mg/g } \\
\text { tissue) }\end{array}$ & $\begin{array}{l}\text { RNA (mg/g } \\
\text { tissue) }\end{array}$ \\
\hline Group I & $1.88 \pm 0.11$ & $2.71 \pm 0.12$ & $3.67 \pm 0.15$ & $10.85 \pm 0.52$ \\
Group II & $0.93 \pm 0.15$ & $1.22 \pm 0.07$ & $7.49 \pm 0.34$ & $16.84 \pm 0.67$ \\
Group III & $1.06 \pm 0.08$ & $1.52 \pm 0.09$ & $5.98 \pm 0.81$ & $14.67 \pm 0.27$ \\
Group IV & $1.37 \pm 0.08$ & $2.27 \pm 0.08$ & $4.45 \pm 0.17$ & $13.14 \pm 0.50$ \\
Group V & $1.61 \pm 0.08$ & $2.58 \pm 0.08$ & $3.98 \pm 0.61$ & $11.52 \pm 0.59$ \\
Group VI & $1.83 \pm 0.08$ & $2.67 \pm 0.09$ & $3.72 \pm 0.14$ & $11.08 \pm 0.43$ \\
\hline
\end{tabular}

Values are expressed as mean \pm SD $(n=6)$. $(1$ unit $=\mu$ moles of $\pi$ liberated $/ \mathrm{min})$

group of animals. When compared to Group I, $\mathrm{Na}^{+} / \mathrm{K}^{+}$-ATPase activity was decreased significantly by 2 -fold; the decrement in the activity of $\mathrm{Mg}^{2+}$-ATPase was found to be $56 \%$ in Group II. The increment in enzymes was observed in other treatment groups. The level of DNA in Group II gets elevated by 4-fold; when compared to Group I. The increment in the levels of RNA in Group II was found to be $55 \%$ when compared to Group I. In Group III-VI, the marker enzyme levels were decreased compared to Group II.

\section{DISCUSSION}

The phytoconstituents were responsible for the therapeutic properties of the plants [24]. From the phytochemical screening, it was found that the numbers of phytoconstituents were more in ethanol extract followed by ethyl acetate extract and petroleum ether extract. All these extracts were found to be nontoxic up to the dose $2000 \mathrm{mg} / \mathrm{kg}$ in acute toxicity study. Based on the in vitro cytotoxic evaluation on various cell lines, the whole plant of $P$. corymbosa Lamk. exhibited potential activity against breast cancer cell line [22]. EAC is an experimental breast cancer derived from spontaneous mouse adenocarcinoma. EAC causes rapid buildup and accumulation of ascitic fluid [38] in the peritoneal cavity. In EAC bearing mice, the body weight, ascitic volume [39], and viable cell count was increased. Supplementation of WPC extract reverses the altered levels of body weight, MST, percentage of life span, tumor volume, PCV and incremented, the non-viable cell count indicating its cytotoxicity toward 
cancer cells. The order of efficacy of extracts wasEEPC > EAEPC > PEEPC. The EEPC has potential antitumor activity similar to that of reference drug, 5- Fluorouracil. On hematological investigation, the decrease in RBC and hemoglobin was found which may be due to the deficiency of iron or due to the hemolytic or myelopathic conditions in EAC mice [40]. The significant increase in WBC count and neutrophils in tumor bearing mice was due to its primary defense mechanism [41]. Decreased lifespan was due to the low Hb levels in cancerous condition [42]. The above conditions were reversed in drug treated groups which evidenced the protective action of WPC extracts on the hematopoietic system. Because of free radical generation in cancer cells, the leakage of lysosomal enzymes [43] occurs due to loss of membrane integrity. Lysosomal specific marker enzymes include Cathepsin-D [44-46], Acid phosphatase and $\beta$-D-glucuronidase [47-50]. Liver enzyme markers such as 5'nucleotidase [51], Lactate dehydrogenase [52-54], potential tumor markers used to assess the progression of the proliferating malignant cells. Among the various extracts of WPC, EEPC produces potential action which may be due to the presence of flavonoids which scavenges the free radicals and protects membrane integrity $[36,38,55]$. Treatment with EEPC elevates antioxidant enzymes such as serum total protein, superoxide dismutase, catalase, reduced glutathione, and glutathione peroxidase activity in $\mathrm{CCl}_{4}$ induce hepatotoxicity [8] and alloxan-induced diabetic rats [7]. Oxidative stress accumulation causes significant decrease in the ion transport proteins [56] such as sodium potassium ATPase and magnesium ATPase in liver of cancer bearing mice $[57,58]$. Chemo resistance occurs by this mechanism due to efflux of drugs from transport proteins [59]. In the EEPC treated EAC-control, membrane bound ATPase levels were increased. Flavonoids influence the permeability of bio membranes by interacting with ATPase pumps in the animal cell thereby regaining their normal efficiency [59] and resumed the normal function [60]. Elevated levels of hepatic nucleic acids DNA and RNA were observed in disease control [61-64] but in treatment groups, reduction in their levels were observed. Attainment of nucleic acids levels to near normal was observed in EEPC treated groups. This proves that the drug has the potential to inhibit the proliferation of cancer cells, can stabilize, and restore the system to its normal physiological function.

As per literature, the chief constituents present in WPC were lupeol [65], stigmasterol [66], beta sitosterol [66], gamma sitosterol [66], camelligenin A [67], apoanagallosaponin IV [67], 5 hydroxy methyl furfural [68], and 9, 2, hexadecanoic acid [68]. These compounds were known for its anticancer property in various malignant neoplasms. In breast cancer, lupeol acts by downregulating the Bcl-2 and bcl-XL protein expression which induces the apoptosis process in breast cancer cell line MCF-7 [69], it also reduces cell migration in non-small cell lung cancer[70,71]. Phytosterols such as Stigmasterol and beta sitosterol showed cytotoxic potential against breast cancer cell line [72]; the stigmasterol reduces the tumor development by activation of protein phosphatase 2A causing apoptosis in EAC induced mice via stimulation of antioxidant enzymes [73].

\section{CONCLUSION}

From the above findings, it was concluded that P. corymbosa Lamk. possess antitumor activity. The mechanism by which it elucidates its anticancer potential has to be determined.

\section{ACKNOWLEDGEMENT}

The authors are highly thankful to Dean, Madras Medical College and Department of Pharmacology, College of Pharmacy, Madras Medical College, Chennai -3 .

\section{CONFLICT OF INTEREST}

The authors do not have any conflict of interest.

\section{AUTHOR'S CONTRIBUTION}

All the authors contributed equally in research.

\section{REFERENCES}

1. Rui-Hua X, Pelicano H, Zhou Y, Carew J, Li F, Bhalla KN, et al. Inhibition of glycosides in cancer cells: A novel strategy to overcome drug resistance associated with mitochondrial respiratory defect and hypoxia. Cancer Res 2005;65:613-21.

2. Perillo B, Di Donato M, Pezone A, Di Zazzo E, Giovannelli P, Galasso G, et al. ROS in cancer therapy: The bright side of the moon. Exp Mol Med 2020;52:192-203.

3. Jakimiuk K, Wink M, Tomczyk M. Flavonoids of the Caryophyllaceae. Phytochem Rev 2021;2021:1302.

4. Nadkrarni KM. Indian Materia Medica with Ayurvedic, Unani Tibbi, Siddha, Allopathic, Homeopathic, Naturopathic and Home Remedies, Appendices and Indexes. Vol. 1. Bombay: Popular Prakashan Pvt. Ltd.; 1976. p. 997.

5. Chopra RN, Nayar SL, Chopra IC. Glossary of Indian Medicinal Plants. Vol. 1. New Delhi: CSIR; 1956. p. 199.

6. Chetty KM, Shivaji K, Rao KT. Polycorpaea corymbosa L, Flowering Plants of Chitoor District, Andrapradesh, India; 2008.

7. Nishanthini A, Mohan V. Antioxidant activity of Polycarpaea corymbosa L. whole plant of alloxan induced diabetic rats. World J Pharm Pharm Sci 2013;4:343-51.

8. Nishanthini A, Balamurugan K, Mohan VR. Hepatoprotective and antioxidant effect of Polycarpaea corymbosa against $\mathrm{CCl}_{4}$ induced hepatotoxicity in rats. Int J Adv Life Sci 2012;5:104-11.

9. Balamurugan K, Devi GS, Mohan VR. In vitro antioxidant activity of whole plant extract of Polycarpaea corymbosa (L.) Lam. (Caryophyllaceae). World J Pharm Pharm Sci 2013;2:3676-90.

10. Sindhu S, Manorama S. Screening of Polycarpaea corymbosa Lam. (Caryophyllaceae) for its in vitro antioxidant activity. Asian J Pharm Clin Res 2012;5:175-8.

11. Balamurugan K, Devi GS, Mohan VR. Anti-inflammatory activity of whole plant of Polycarpaea corymbosa Lam. (Caryophyllaceae). Pharm Sci Mon 2012;3:3336-41.

12. Sindhu S, Manorama S. Anti-inflammatory activity of methanolic extract of Polycarpaea corymbosa Lam. (Caryophyllaceae). Int J Adv Res 2013;1:1-5.

13. Balamurugan K, Devi GS, Mohan VR. Antiulcer activity of Polycarpaea corymbosa (L.) Lam. whole plant extracts (Caryophyllaceae). Int J Biol Med Res 2013;4:3379-82.

14. Sindhu S, Manorama S. Study of the anti-ulcerogenic activity of the methanolic extracts of Polycarpaea corymbosa Lam. (Caryophyllaceae) in wistar rats. Int J Pharm Res Schl 2014;3:126-30.

15. Reddy KY. Acute toxicity and anti-ulcer activity of Polycarpaea corymbosa L. in albino wistar rats. Int J Pharm Pract Drug Res 2012;2:39-45

16. Balamurugan K, Devi GS. Anti-diarrhoeal activity of Polycarpaea corymbosa (L.) Lam. whole plant extracts (Caryophyllaceae). J Harmon Res Pharm 2013;2:100-3.

17. Sindhu S, Manorama S. Antimicrobial activity of Polycarpaea corymbosa Lam. (Caryophyllaceae) against human pathogens. J Chem Pharm Res 2012;4:4014-9.

18. Sindhu S, Manorama S. Investigating anti nociceptive activity of Polycarpaea corymbosa Lam. (Caryophyllaceae) in standard experimental animal. Int J Pharm Pharm Sci 2014;6:161-3.

19. Varadharajan R, Rajalingam D. Hepatoprotective effect of Polycarpaea corymbosa L. against $\mathrm{CCl}_{4}$ induced hepatotoxicity in rats. Int $\mathrm{J}$ Pharmacother 2012;2:18-23.

20. Abirami MS, Monika N. Induction of apoptosis in human liver carcinoma cell line and the safety of liver by Polycarpaea corymbosa Lam. J Glob Trends Pharm Sci 2018;9:5861-6.

21. Mohan VR, Balamurugan K, Devi GS. Fertility enhancement of Polycarpaea corymbosa (L.) Lam (Caryophyllaceae) whole plant on male albino rats. Asian J Pharm Clin Res 2013;6:151-5.

22. Abirami MS, Muthusamy P. In-vitro cytotoxic activity of various extracts from whole plant of Polycarpaea corymbosa Lam. J Glob Trends Pharm Sci 2016; 7:2997-3000.

23. Prabhavathi RM, Prasad MP, Jayaraman M. Studies on qualitative and quantitative phytochemical analysis of Cissus quadrangularis. Adv Appl Sci Res 2016;7:11-7.

24. Harborne JB. Phytochemical Methods. $2^{\text {nd }}$ ed. London: Chapman and Hall; 1973. p. 49-188.

25. OECD 423. OECD Guideline For Testing of Chemicals Acute Oral Toxicity-Acute Toxic Class Method Adopted. Paris: OECD; 2001.

26. Chandran A, Arunachalam G. Evaluation of in-vivo anticancer activity of Scaevola taccada Roxb. Against Ehrlich Ascites Carcinoma in Swiss albino mice. J Pharm Sci Res 2015;7:626-32. 
27. Mukherjee K. Medical Laboratory Technology a Procedure Manual for Routine Diagnostics Tests. New York: Tata McGraw Hill Publishing Company Limited; 2010.

28. Sapolsky AI, Atlman RD, Li DS. Cathepsin D activity in normal and osteoarthritic human cartilage. Fed Proc 1973;32:1489-93.

29. Kawai Y, Anno K. Mucopolysaccharide degrading enzymes from the liver of squid, Ommastrephes slonai pacificus I. Hyaluronidase. Biochem Biophys Acta 1971;242:428-36.

30. Fiske GH, Subbarow. The calorimetric determination of phosphorus. J Biol Chem 1925;5:375-400.

31. Heppel LA. Hilmoe RJ. Purification and properties of 5'-nuclotidase. J Biol Chem 1951;188:665-76.

32. King J. The hydrolases or oxidoreductase, Lactate dehyrogenase. In: Van D, editors. Practical Clinical Enzymology. Kolkata, West Bengal: Norst and Company Ltd.; 1965. p. 83-93.

33. Bonting SL. In: Bittar EE, editor. $\mathrm{Na}^{+}-\mathrm{K}^{+}$activated Adenosine Triphosphate and Cation Transport in Membrane and Ion Transport. London: Wiley Interscience; 1970. p. 257-363.

34. Ohinishi T, Suzuki T, Ozawa K. A comparative study of plasma membrane magnesium ion ATPase activities in normal regenerating and malignant cells. Biochem Biophys Acta 1982;684:67-74.

35. Schneider WC. Phosphorous compounds in animal tissues. Isolation, extraction and estimation of deoxypentose nucleic acid and pentose nucleic acid. J Biol Chem 1945;161:293-303.

36. Arora A, Byrem TM, Nair MG, Strasburg GM. Modulation of liposomal membrane fluidity by flavonoids and isoflavonoids. Arch Biochem Biophys 2000;373:102-9.

37. Novikoff AB, Hers HG, Van Hoff F. Lysosomes and Storage Diseases. Vol. 5. New York: Academic Press; 1973. p. 1-41.

38. Papac RJ. Origins of cancer therapy. Yale J Biol Med 2001;74:391-8.

39. Fecchio D, Sirois P, Russo M, Jancar S. Studies on inflammatory response induced by Ehrlich tumor in mice peritoneal cavity. Inflammation 1990;14:125-32.

40. Motzer RJ, Mazumder M, Bacik J, Berg W. Survival and Prognostic stratification of 670 patients with advanced renal cell carcinoma. J Clin Oncol 1999; 17:2530-40

41. Fenninger LD, Mider GB. Energy and nitrogen metabolism in cancer. Adv Cancer Res 1954;2:229.

42. Zein N, Enaiat K, Fatma M, EL Sayed Z. Anti- Proliferative effect of Eucalyptus camaldulensis against Ehrlich ascites carcinoma (EAC) cells in Swiss albino mice in vivo. World J Pharm Res 2015;4:272-86.

43. Fenninger LD, Mider GB. In: Grenstein JP. Haddow A, editors. Advances in Cancer Research. Vol. 2. New York: Academic Press; 1954. p. 244

44. Geetha R. Effect of Tocopherol on doxorubicin induced changes in rat heart lysosomal enzymes. Ind J Exp Biol 1993;31:288-90.

45. Mathieu M, Rochefort H, Barenton B, Prebois C, Vignon F. Interactions of cathepsin-D and insulin like growth factor II (IGF-II) on the IGF-II/mannose -6- phosphate receptor in human breast cancer cells and possible consequences on mitogenic activity of IGF-II. Mol Endocrinl 1990;4:1327-35

46. Garcia M, Derocq D, Pujol P, Rochefort H. Over expression of transfected cathepsin-D in transformed cells increases their malignant phenotype and metastatic potency. Oncogene 1990;5:1809-14.

47. Karunairatnam MC, Kerr LM, Levvy GA. The glucuronide synthesizing system in the mouse and its relationship to $\beta$-D-glucuronidase. Biochem J 1949;45:496-9.

48. Huang XF, Wang CM, Dai XW, Li ZJ, Pan BR, Yu LB, et al. Expression of chromogranin A and cathepsin D in human primary hepatocellular carcinoma. World J Gastroenterol 2000;6:693-8.

49. Cohen SL, Bittner JJ. The effect of mammary tumors on the glucuronidase and esterase activities in a number of mouse strains. Cancer Res 1951;11:723-6.

50. De Duve C, Pressman BC, Gianetto R, Wattiaux R, Applemans F. Tissue fractionation studies, Intracellular distribution patterns of enzymes in rat-liver tissue. Biochem J 1955;60:604-17.

51. Matsura SS, Kato EK, Tashiro Y. Ferritin immune electron microscopic localization of 5 ' nucleotidase on rat liver cell surface. J Cell Biol
1984;99:166-73

52. Ayorinde BT, Akanji MA, Yakubu MT. Alterations in some marker enzymes of liver and kidney damage following chronic administration of aqueous extract of Tapinanthus globiferus leaves to rats. Pharmacogn Mag 2008;2008:S9-14

53. Veena K, Shanthi P, Sachdanandam P. Anticancer effect of kalpaamruthaa on mammary carcinoma in rats with reference to glycoprotein components, lysosomal and marker enzymes. Biol Pharm Bull 2006;29:565-9.

54. Walia M, Mahajan M, Singh K. Serum adenosine deaminase, 5 '- nucleotidase and alkaline phosphatase in breast cancer patients. Indian J Med Res 1995;101:247-9.

55. Sunderman FW. The clinical biochemistry of 5'- nucleotidase. Ann Clin Lab Sci 1990;20:123-39.

56. Suzuki S, Takada T, Sugawara Y, Muto T. Quercetin induces recombinational mutations in cultured cells as detected by DNA finger printing. Jpn J Cancer Res 1991;82:1061-4.

57. Bioj B, Moreto RD, Farias RN. Membrane lipids fatty acids and regulation of membrane bound enzymes. Biochem Biophys Acta 1973;311:67-9

58. Lu A, Gokkuou E, Palandiz O. Vitamin E and ATPases: Protection of ATPase activities by Vitamin E supplementation in various tissues of hypercholesterolemic rats. Int J Vitam Nutr Res 2000;70:3-7.

59. Skekhoren MA, Bonting S1. Transport ATPases: Properties and functions. Physiol Rev 1981;61:1-76.

60. Al-Numair KS, Veeramani C, Alsaif MA, Chandramohan G. Influence of Kaempferol, a flavonoids compound on membrane-bound ATPases in streptozotocin-induced diabetic rats. J Pharm Biol 2014;53:1372-8.

61. Salmon TB, Evert BA, Song B, Doetsch PW. Biological consequences of oxidative stress induced DNA damage in Saccharomyces cerevisiae. Nucleic Acids Res 2004;32:3712-23.

62. Das BK, Koti BC, Gadad PC. Role of Lycopersicon esculentum in diethyl nitrosamine induced and phenol barbital promoted hepato cellular carcinoma. Indian J Health Sci Biomed Res 2016;9:147-52.

63. Lundholm K, Ekman L, Edstrom S, Karlberg I. Protein synthesis in liver tissue under the influence of a methylcholanthrene-induced sarcoma in mice. Cancer Res 1979;39:657-61.

64. Kumar RS, Kumar SV, Rajkapoor B, Pravin N, Dharmasivam M. Chemopreventive effect of Indigofera linnaei extract against diethylnitrosamine induced hepatocarcinogenesis in rats. J Appl Pharm Sci 2016;6:199-209.

65. Modi K, Shah M. Phytochemical investigation and pharmacognostic standardization of Polycarpaea corymbosa Lam. Pharmacogn J 2017;9:895-9

66. Sindhu S, Manorama S. GC-MS determination of bioactive components of Polycarpaea corymbosa Lam. (Caryophyllaceae) Hygeia. J D Med 2013;5:5-9.

67. Manase MJ, Mitaine OA, Miyamoto T, Tanaka C, Delemasure S, Dutartre P, et al. Triterpenoid saponins from Polycarpaea corymbosa Lamk. var. eriantha Hochst. Phytochemistry 2014;100:150-5.

68. Chiang HC. Studies on the constituents of Polycarpaea corymbosa Lam. Taiwan Yaoxue Zazhi 1978;30:114-20.

69. Pitchai D, Roy A, Ignatius C. In vitro evaluation of anticancer potentials of lupeol isolated from Elephantopus scaber L. on MCF -7 cell line. J Adv Pharm Technol Res 2014;5:179-84.

70. Baby TS, Michael BP, Jerard C, Vijayakumar N, Ramachandran R. Study on the antimetastatic and anticancer activity of triterpene compound lupeol in human lung cancer. Int J Pharm Sci Res 2019;10:721-7.

71. Liu K, Zhang X, Xie L, Deng M, Chen H, Song J, et al. Lupeol and its derivatives as anticancer and anti-inflammatory agents: Molecular mechanisms and therapeutic efficacy. Pharmacol Res 2020;164:105373.

72. Ayaz M, Sadiq A, Wadood A, Junaid M, Ullah F, Khan Z. Cytotoxicity and molecular docking studies on phytosterols isolated from Polygonum hydropiper L. Steroids 2018;141:30-5.

73. Ghosh T, Maity TK, Singh J. Evaluation of antitumor activity of stigmasterol, active constituents isolated from Bacopa monneri Linn. Aerial parts against Ehrlich ascites carcinoma in mice. Orient Pharm Exp Med 2011;11:41-9. 